\title{
Secular Change: Confounding Factor or Causative Factor of Inter-population Differences in Modern Japanese Crania?
}

\author{
Makiko KoUCHI $^{1)}$ and Kiyotaka KOIZUMI ${ }^{2)}$ \\ 1) Human Engineering Department \\ Industrial Products Research Institute \\ 2) Noda Kurse
}

\begin{abstract}
Basic statistics on cranial measurements from 15 modern Japanese populations were compiled by the Commission of Anthropological Investigation of Modern Japanese Crania. These data were analyzed in order to evaluate the magnitude of inter-population differences and the influence of secular change on the interpopulation differences. Cranial measurements taken for four populations from the late Edo period were used to estimate the inter-population differences that can be caused by systematic inter-observer measurement errors and by the bias in the sampling. The distance measures based on the measurement items with small intraand inter-observer measurement errors indicate that the inter-population differences in modern Japanese crania are much greater than the differences caused by the measurement error. However, the differences caused by sample bias are as large as some of the inter-population differences. The results of cluster analyses indicate that the influence of secular change can not be ignored. According to the results of discriminant analysis, the key characteristic in determining inter-population difference is maximum cranial breadth. Since secular change is observed in seven out of 13 measurement items with significant inter-population differences, a considerable part of so-called geographic differences among modern Japanese crania is likely to be due to the secular change that took place during the 100 year period required to collect the materials.
\end{abstract}

Key Words Modern Japanese crania, Geographic variation, Secular change

\section{Introduction}

Geographic differences in modern Japanese crania have been considered a key to clarifying the lineage of the Japanese since HASEBE first pointed them out (HASEBE, 1917). Several studies have been published on this subject
(MATSUMURA, 1925; KOHAMA, 1960; IKEDA and TAGAYA, 1980; HANIHARA et al., 1982; KOUCHI, 1983). However, the results are not always easy to interpret. It is necessary to eliminate the effects of confounding factors before interpreting the nature of inter-population differences. 
Systematic inter-observer measurement errors, effects of the bias of the samples, and secular change are possible confounding factors. The influence of systematic inter-observer measurement errors on the results of inter-population comparisons is not negligible, especially when the inter-population difference is small (SAKURA and MIZOGUCHI 1983; KOUCHI and KOIZUMI, 1985; KoIZUMI and KOUCHI, 1988). The only practical way to minimize the effects of the measurement errors is to use reliable measurement items (KoIZUMI and KoúcHI, 1988).

A cranial series may not faithfully represent the mother population because the crania are not sampled randomly. Therefore, it is necessary to know the magnitude of the difference that can be caused by the bias of the samples in order to evaluate the biological significance of interpopulation differences.

The extensive metric data on the modern Japanese crania collected by the Commission of the Anthropological Investigation of Modern Japanese Crania (CAIMJC) are most complete in standardizing the measuring method. The materials investigated by this commission were collected during the period of about 100 years from the 1870 s to the 1970 s. It is known from both somatological and cranial data that a rapid secular change has occurred during this period (SUZUKI, 1969; KOUCHI, 1983, 1986), and it is natural to expect that the materials investigated by CAIMJC are heterogeneous in this respect. However, the influence of the secular change on the inter-population differences in the modern Japanese crania has not been investigated.

The purposes of the present paper are, 1) to examine the magnitude of inter-population differences in modern Japanese crania in reference to the potential differences caused by systematic inter-observer measurement errors and sampling bias, and 2) to investigate the effects of secular change on these same Japanese crania.

\section{Materials}

I. Materials for the analyses of inter-population differences in modern Japanese crania

Basic statistics of 18 cranial measurement items for 15 male modern Japanese populations, including one Ainu population, cited from CAIMJC $(1981,1983)$ are used for this purpose. The number of the samples and the year of collection for each population are shown in Table 1 , and the geographic distribution of the crania in Fig. 1.

II. Control group for the effects of measurement errors

Thirty five relatively well preserved Japanese crania of the late Edo period excavated from Unkoin temple, Fukagawa, Koto-ku, Tokyo, sexed as male by one of the authors (K.K.), were

Table 1. Modern male Japanese materials investigated by the Commission of Anthropological Investigation of Modern Japanese Crania (1981, 1983)

\begin{tabular}{|c|c|c|c|c|c|}
\hline \multirow[b]{2}{*}{ Population } & \multirow[b]{2}{*}{$\mathrm{N}$} & \multicolumn{4}{|c|}{ Period of collection } \\
\hline & & M & $\mathrm{T}$ & $\mathrm{S} 1$ & $\mathrm{~S} 2$ \\
\hline 1 Tohoku & 48 & $*$ & $*$ & $*$ & \\
\hline 2 Kanto & 88 & & $*$ & $*$ & \\
\hline 3 Chiba & 77 & & & $*$ & \\
\hline 4 Chubu & 96 & & & & * \\
\hline 5 Niigata & 56 & & $*$ & $*$ & \\
\hline 6 Hokuriku & 51 & & & $*$ & \\
\hline 7 Kyoto & 53 & $*$ & $*$ & $*$ & \\
\hline 8 Osaka-1 & 22 & $*$ & $*$ & $*$ & \\
\hline 9 Osaka-2 & 27 & & & & * \\
\hline $10 \mathrm{Kinki}$ & 15 & & & & * \\
\hline 11 Nagasaki & 59 & & & & $*$ \\
\hline 12 Kumamoto & 50 & & & & $*$ \\
\hline 13 Northern Kyushu & 95 & $*$ & $*$ & $*$ & \\
\hline 14 Kagoshima & 26 & & & & $*$ \\
\hline $15 \mathrm{Ainu}$ & 38 & $*$ & & & \\
\hline
\end{tabular}

M: 1870s-1912; T: 1912-1926; S1: 1926-1944; S2: 1945-1970s. 


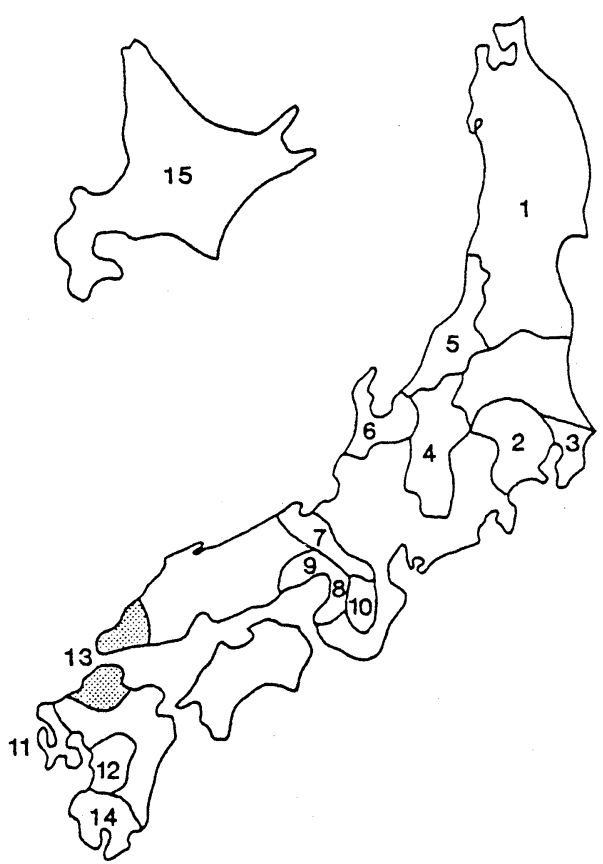

Fig. 1. Areas from which the samples of modern crania were collected. Numbers correspond to those in Table 1. Shadowed areas belong to No. 13.

used (Unkoin-1 series). Ten observers measured this series of crania. The data measured by the 10 observers are treated as if they are taken from 10 different populations, and will be referred to as $\mathrm{U}-1, \mathrm{U}-2, \ldots, \mathrm{U}-10$ in the following text. The differences between them are caused by systematic inter-observer errors. The results of the analyses of measurement errors of these data have already been published (KOUCHI and KoIZUMI, 1985). Only the male crania were used throughout the present study.

III. Control group for the effects of the bias of the samples

Four series of crania are used for this purpose. The first series is Unkoin-1 series. The second consists of 30 relatively well-preserved crania of the late Edo period also excavated from Unkoin temple. They are sexed as male and measured by K.K. (Unkoin-2 series). Because these crania are randomly sampled from the same series as Unkoin-1, the differences between Unkoin-1 and Unkoin-2 series are considered to be caused by the bias of the samples produced by chance.

Two other series are also from the late Edo period and were excavated from Tokyo. One consists of 25 crania excavated from Higashiueno, Taito-ku, Tokyo. They were sexed as male by K.K. and measured by M.K. The other consists of 65 male crania excavated from Joshinji temple, Koto-ku, Tokyo, and measured by CAIMJC (1983). Because both series are from the same period (late Edo period) and district (Tokyo) as the Unkoin-1 and Unkoin-2 series, the differences between Unkoin, Higashiueno and Joshinji series are considered to be caused by the bias in the sampling.

IV. Materials for the study of secular change

To investigate the secular change during and after the Edo period, the data on the 45 male crania of the early to middle Edo period excavated from Hitotsubashi High School in Tokyo (CAIMJC, 1983) and 37 male crania of the late Edo period excavated from Kita-ku, Osaka (KANDA, 1959) were used as well as the above mentioned 4 cranial series of the late Edo period.

\section{Measurement Items}

Eighteen measurement items used for the analyses are shown in Table 3. They were selected according to the criterion that the total of intraand inter-observer error variance is less than $10 \%$ of total variance (KOUCHI and KOIZUMI, 1985). The radii and nasal height were measured according to HOWELLS (1973), and others according to MARTIN and SALLER (1957). 


\section{Methods}

Differences between populations were measured by the mean square distance and PENROSE's shape distance. These distance measures were adopted in the present study because variance-covariance matrix was not necessary for their calculation. Also they have been used in the analyses of the inter-population differences in Japanese materials. Cluster analysis employing the group average method was used to obtain a dendrogram to show the interpopulation relationship based on each distance measure.

ANOVA was used to identify the measurement items showing significant inter-population differences by testing the equality of the means of 14 modern populations, excluding the Ainu.

A t-test was used to examine the effect of the secular change by testing the equality of group means between the two populations from one region belonging to two consecutive time periods. This was done for both the Kanto and Kinki districts, using the following data:

(1) Kanto district

i E1: Data on 45 male crania of the early to middle Edo period from Hitotsubashi, Tokyo, by CAIMJC.

ii E2: Pooled data of Unkoin-1 (measured by K.K.), Unkoin-2, Higashiueno and Joshinji series of the late Edo period.

iii M1: Pooled data of Chiba and Kanto by CAIMJC. The materials were collected before World War II,

(2) Kinki district

i E2: The data of 37 male crania of the late Edo period (1770-1830) excavated in Osaka (KANDA, 1959).

ii M1: Pooled data of Kyoto and Osaka-1 by CAIMJC. The materials were collected before World War II.

iii M2: Pooled data of Osaka-2 and Kinki by
CAIMJC. The materials were collected after World War II.

Discriminant analysis was used in order to identify the best combination of the measurement items. This distinguished between the two groups obtained by the cluster analyses. The discriminant function was calculated by the stepwise method (BMDP7M) using the 18 measurements of 14 modern Japanese populations, excluding the Ainu.

\section{Results}

I. Distance measures and cluster analysis

Table 2 shows the PENROSE's shape distances $\left(\sqrt{\mathrm{Cz}^{2}}\right)$. The median for the 10 values of U-1 to U-10 are shown for the Unkoin-1 series. The distances between 10 samples of Unkoin-1 series are $0.05-0.17$ (mean $=0.11)$. The inter-population differences of the modern Japanese samples are much greater than the differences caused by measurement errors. Among the 91 distances shown, for 14 modern Japanese samples, about $80 \%$ are greater than 0.27 , which is the maximum value of the distances between the four samples from Edo period.

Fig. 2 shows the dendrogram based on the PENROSE's shape distance. The groups U-1 to U-10, representing the Unkoin-1 series measured by 10 different observers, make one cluster. Twenty eight populations used for the present anlaysis are divided into the following three clusters:

Cluster 1: All of the 13 populations of the Edo period (10 of Unkoin-1 series, Unkoin-2, Higashiueno and Joshinji series) and 10 populations of modern Japanese (Northern Kyushu, Kanto, Kumamoto, Chiba, Kyoto, Osaka-1, Tohoku, Chubu, Niigata, and Hokuriku)

Cluster 2: Ainu.

Cluster 3: Osaka-2, Kinki, Nagasaki and Kagoshima. 


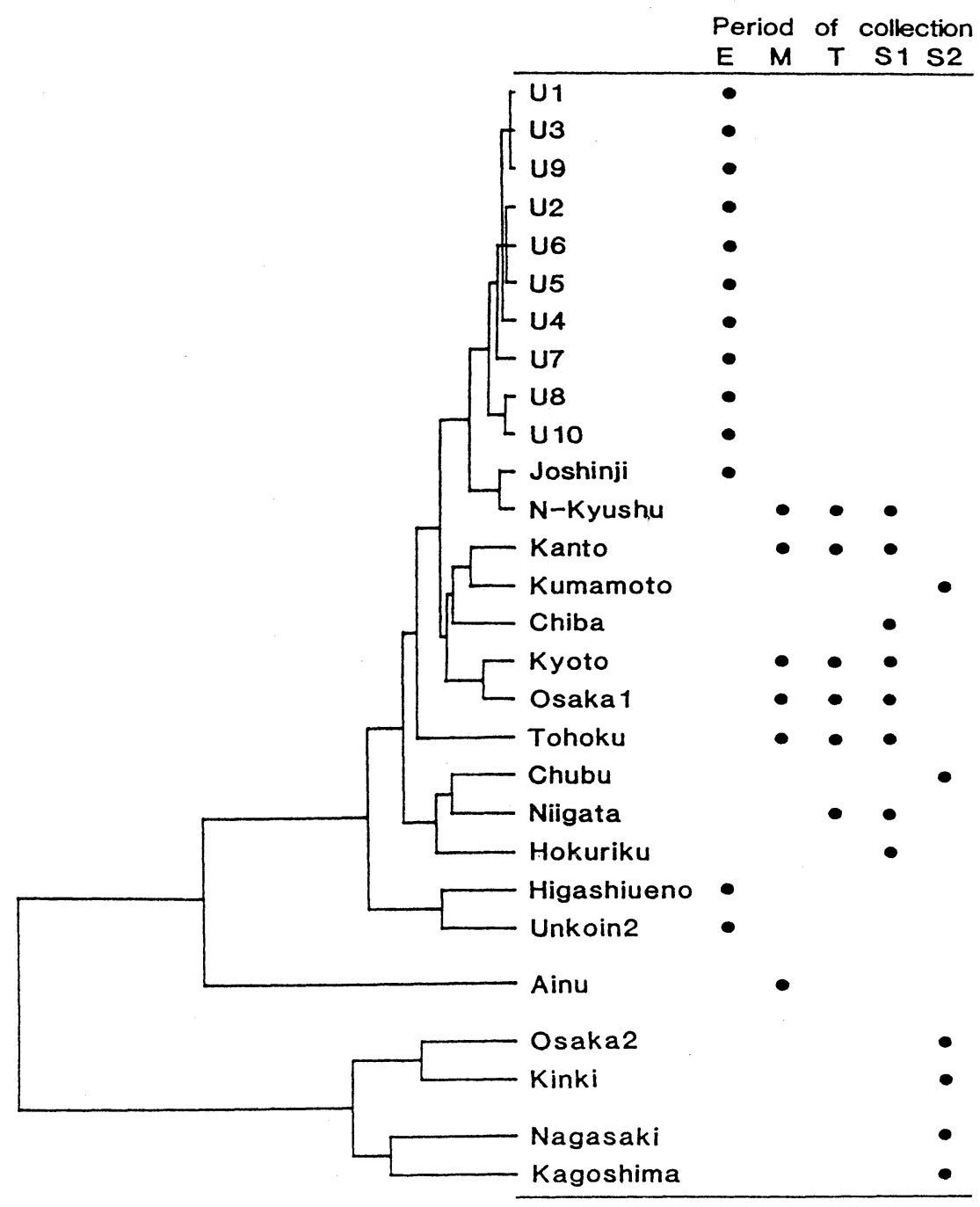

Fig. 2. Dendrogram based on PENROSE's shape distances.

Note: E: late Edo period, M: Meiji period (1868-1912), T: Taisho period (1912-1926), S1; Showa before and during WWII (1926-1944), S2: Showa after WWII (1945-1970s).

Table 2 shows that Tohoku, Niigata, Hokuriku and Northern Kyushu, which belong to cluster 1, are closer to the populations of the Edo period than to other modern Japanese populations. Ten modern Japanese populations belonging to cluster 1 are distributed over a wide area from the Tohoku to the Kyushu districts, and there is no geographic implication in their craniometric affinity. This is also true for Nagasaki, Kagoshima and Osaka-Kinki, which belong to cluster 3 .

Similarity in time period is another possible reason these populations clustering together. To examine this possibility, the period of about 100 
Table 2. PENROSE's shape distances $\left(\sqrt{\mathrm{Cz}^{2}}\right.$, decimal points are omitted)

\begin{tabular}{lllllllllllllllllll}
\hline & 1 & 2 & 3 & 4 & 5 & 6 & 7 & 8 & 9 & 10 & 11 & 12 & 13 & 14 & 15 & 16 & 17 & 18 \\
\hline 2 H-Ueno & 27 & & & & & & & & & & & & & & & & \\
3 Unkoin-2 & 21 & 23 & & & & & & & & & & & & & & & \\
4 Joshinji & 16 & 27 & 22 & & & & & & & & & & & & & & & \\
5 Tohoku & 22 & 34 & 28 & 25 & & & & & & & & & & & & & \\
6 Kanto & 24 & 45 & 35 & 22 & 28 & & & & & & & & & & & & \\
7 Chiba & 22 & 35 & 31 & 23 & 22 & 21 & & & & & & & & & & & \\
8 Chubu & 26 & 38 & 36 & 22 & 34 & 26 & 21 & & & & & & & & & & \\
9 Niigata & 24 & 34 & 27 & 20 & 31 & 29 & 26 & 21 & & & & & & & & & \\
10 Hokuriku & 24 & 30 & 33 & 20 & 25 & 31 & 24 & 24 & 23 & & & & & & & & \\
11 Kyoto & 23 & 40 & 38 & 23 & 32 & 21 & 22 & 26 & 32 & 28 & & & & & & & \\
12 Osaka-1 & 25 & 37 & 36 & 20 & 29 & 22 & 24 & 26 & 33 & 25 & 15 & & & & & & \\
13 Osaka-2 & 37 & 55 & 46 & 36 & 47 & 26 & 36 & 36 & 41 & 45 & 29 & 35 & & & & & \\
14 Kinki & 44 & 60 & 55 & 40 & 52 & 32 & 38 & 36 & 43 & 45 & 32 & 38 & 26 & & & & \\
15 Nagasaki & 37 & 57 & 51 & 39 & 39 & 27 & 29 & 36 & 41 & 39 & 26 & 33 & 36 & 33 & & & \\
16 Kumamoto & 24 & 39 & 34 & 22 & 28 & 18 & 21 & 28 & 33 & 27 & 23 & 18 & 29 & 35 & 33 & & \\
17 N-Kyushu & 17 & 31 & 26 & 13 & 25 & 19 & 23 & 28 & 28 & 25 & 17 & 14 & 31 & 39 & 35 & 16 & \\
18 Kagoshima & 37 & 50 & 47 & 34 & 43 & 32 & 31 & 29 & 39 & 40 & 22 & 30 & 33 & 33 & 30 & 37 & 32 & \\
19 Ainu & 44 & 44 & 33 & 51 & 47 & 56 & 50 & 62 & 54 & 57 & 58 & 56 & 64 & 77 & 70 & 54 & 48 & 66 \\
\end{tabular}

Note: Sample 1 is Unkoin-1. Median value of 10 samples, U-1 to U-10 is shown.

years, during which the cranial materials were collected was divided into the following four time periods, and each sample was examined for the period of collection:

M: Meiji period (1868-1912). Most of the materials belonging to this period were collected during the $1900 \mathrm{~s}$,

T: Taisho period (1912-1926),

S1: Showa period before and during World War II (1926-1944),

S2: Showa period after World War II (19451970s).

The period in which the materials were collected is also shown in Fig. 2. The materials of the four samples belonging to cluster 3 were collected during the period $\mathrm{S} 2$, and the materials of most of the 10 modern Japanese samples belonging to the same cluster as the samples of the Edo period were collected before World War II. This fact suggests that secular change may play an important role in determining the inter- population differences of modern Japanese crania.

The results, based on mean square distance, are basically the same as those based on the PENROSE's shape distance.

II. Test of significance of inter-population differences

The equality of group means were tested between the 14 modern Japanese populations by ANOVA. The results are shown in Table 3. The means are significantly different at the $5 \%$ level in four measurement items (minimum frontal breadth, NAR, SSR and PRR), and at the $1 \%$ level in nine items (maximum cranial length, cranial base length, maximum cranial breadth, basion-bregmatic height, sagittal frontal arc, sagittal frontal chord, facial length, upper facial height, and VRR).

Table 4 shows the results of the t-test for the 
Table 3. Results of the significance test of the equality of the means of 14 modern Japanese populations

\begin{tabular}{|c|c|c|c|}
\hline Measurement item (MARTIN's no.) & F-value & df1 & $\mathrm{df} 2$ \\
\hline 1 Maximum cranial length (1) & 3.38 & 13 & $745^{* *}$ \\
\hline 2 Cranial base length (5) & 2.86 & 13 & $744^{* *}$ \\
\hline 3 Maximum cranial breadth (8) & 4.60 & 13 & $743^{* *}$ \\
\hline 4 Minimum frontal breadth (9) & 2.02 & 13 & $745^{*}$ \\
\hline 5 Basion-bregmatic height (17) & 6.23 & 13 & $743 * *$ \\
\hline 6 Sagittal frontal arc (26) & 2.73 & 13 & $743 * *$ \\
\hline 7 Sagittal frontal chord (29) & 2.70 & 13 & $743 * *$ \\
\hline 8 Facial length $(40)$ & 2.96 & 13 & $645 * *$ \\
\hline 9 Bizygomatic breadth (45) & 1.43 & 13 & $732 \mathrm{~ns}$ \\
\hline 10 Middle facial breadth (46) & 0.93 & 13 & $737 \mathrm{~ns}$ \\
\hline 11 Upper facial height (48) & 3.13 & 13 & $649 * *$ \\
\hline 12 Nasal breadth (54) & 1.48 & 13 & $743 \mathrm{~ns}$ \\
\hline 13 Nasal height (NLH)+ & 1.24 & 13 & $745 \mathrm{~ns}$ \\
\hline 14 Upper alveolar breadth (22) & 1.26 & 13 & $634 \mathrm{~ns}$ \\
\hline 15 Vertex radius $(\mathrm{VRR})+$ & 5.38 & 13 & $741 * *$ \\
\hline 16 Nasion radius (NAR) + & 1.92 & 13 & $745^{*}$ \\
\hline 17 Subspinal radius $(\mathrm{SSR})+$ & 1.79 & 13 & $741 *$ \\
\hline 18 Prosthion radius $(\mathrm{PRR})+$ & 1.79 & 13 & $645^{*}$ \\
\hline
\end{tabular}

ns: not significant; *: significant at the $5 \%$ level; ${ }^{* *}$ : significant at the $1 \%$ level; + : after HOWELLS (1973).

differences between populations from the same district but different periods. In the Kanto district, a significant difference between E1 (early to middle Edo) and E2 (late Edo) samples was observed only in cranial base length. From E2 to M1 (before WWII), significant increases were observed in cranial base length, sagittal frontal chord $(p<0.05)$, maximum cranial breadth, basion-bregmatic height, and upper facial height $(\mathrm{p}<0.01)$.

In the Kinki district, significant differences between E2 (lato Edo period) and M1 (before WWII) were observed in nasal breadth $(\mathrm{p}<0.01)$ and upper alveolar breadth $(\mathrm{p}<0.05)$. From M1 (before WWII) to M2 (after WWII) cranial base length decreased $(p<0.05)$, and maximum cranial breadth, VRR $(p<0.05)$, sagittal frontal arc and sagittal frontal chord $(\mathrm{p}<0.01)$ increased.

The measurement items which exhibited significant temporal differences (i.e., the dif- ferences between the samples from different time periods) are not exactly the same in the Kanto and Kinki districts. Additionally, the direction of the secular change is sometimes inconsistent as observed in cranial base length in the Kanto district.

Of the 13 measurement items with significant inter-population differences (Table 3), seven items exhibited significant differences between the populations from the same district but different period (Table 4). For maximum cranial length, minimum frontal breadth, facial length, NAR, SSR, and PRR, geographic differences were significant, but the temporal differences were not.

\section{Discriminant analysis}

The stepwise variable selection and discriminant function analyses were carried out to find the best combination of the smallest number of 
Table 4. Comparison of male Japanese crania from the same district but different periods: Results of t-test

\begin{tabular}{|c|c|c|c|c|c|c|}
\hline \multirow[b]{2}{*}{ Measurement item } & \multicolumn{3}{|c|}{ Kanto district } & \multicolumn{3}{|c|}{ Kinki district } \\
\hline & $\mathrm{E} 1 \mathrm{vs}$ & $\mathrm{E} 2$ & $\mathrm{E} 2 v s . \mathrm{M} 1$ & $\mathrm{E} 2 v$ & s. M1 & M1 vs. M2 \\
\hline 1 Maximum cranial length & 183.3 & $182.0 \mathrm{~ns}$ & $181.1 \mathrm{~ns}$ & 178.1 & $178.1 \mathrm{~ns}$ & $178.0 \mathrm{~ns}$ \\
\hline 2 Cranial base length & 102.8 & $101.1 * *$ & $102.3 *$ & 100.7 & $101.6 \mathrm{~ns}$ & $99.9 *$ \\
\hline 3 Maximum cranial breadth & 138.5 & $138.7 \mathrm{~ns}$ & $141.4 * *$ & 140.6 & $140.9 \mathrm{~ns}$ & $143.1 * *$ \\
\hline 4 Minimum frontal breadth & 93.1 & $94.1 \mathrm{~ns}$ & $95.1 \mathrm{~ns}$ & 92.6 & $93.0 \mathrm{~ns}$ & $93.9 \mathrm{~ns}$ \\
\hline 5 Basion-bregmatic height & 137.6 & $136.5 \mathrm{~ns}$ & $139.1 * *$ & 138.3 & $138.8 \mathrm{~ns}$ & 139.0 ns \\
\hline 6 Sagittal frontal arc & 127.4 & $126.7 \mathrm{~ns}$ & $127.9 \mathrm{~ns}$ & 125.4 & $125.7 \mathrm{~ns}$ & $130.1 * *$ \\
\hline 7 Sagittal frontal chord & 112.0 & $111.3 \mathrm{~ns}$ & $112.3 *$ & 109.9 & $111.1 \mathrm{~ns}$ & $113.5^{* *}$ \\
\hline 8 Facial length & 100.8 & $99.4 \mathrm{~ns}$ & $99.1 \mathrm{~ns}$ & 99.8 & $98.1 \mathrm{~ns}$ & $98.2 \mathrm{~ns}$ \\
\hline 9 Bizygomatic breadth & 135.3 & $134.7 \mathrm{~ns}$ & $135.1 \mathrm{~ns}$ & 132.8 & $133.5 \mathrm{~ns}$ & $134.4 \mathrm{~ns}$ \\
\hline 10 Middle facial breadth & 100.1 & $100.1 \mathrm{~ns}$ & $99.2 \mathrm{~ns}$ & 99.9 & $98.7 \mathrm{~ns}$ & $97.5 \mathrm{~ns}$ \\
\hline 11 Upper facial height & 69.7 & $69.1 \mathrm{~ns}$ & $71.4 * *$ & 68.4 & $69.2 \mathrm{~ns}$ & $70.6 \mathrm{~ns}$ \\
\hline 12 Nasal breadth & 25.7 & $25.8 \mathrm{~ns}$ & $25.7 \mathrm{~ns}$ & 26.7 & $25.5^{* *}$ & $26.2 \mathrm{~ns}$ \\
\hline 13 Nasal height & 51.8 & $52.0 \mathrm{~ns}$ & $52.4 \mathrm{~ns}$ & - & $52.3-$ & $52.6 \mathrm{~ns}$ \\
\hline 14 Upper alveolar breadth & 66.1 & $66.3 \mathrm{~ns}$ & $65.8 \mathrm{~ns}$ & 64.2 & $66.4^{*}$ & $65.3 \mathrm{~ns}$ \\
\hline 15 Vertex radius & 124.8 & $125.5 \mathrm{~ns}$ & $126.3 \mathrm{~ns}$ & - & $126.5-$ & $128.2 *$ \\
\hline 16 Nasion radius & 95.4 & $94.3 \mathrm{~ns}$ & $94.4 \mathrm{~ns}$ & - & $93.9-$ & $94.2 \mathrm{~ns}$ \\
\hline 17 Subspinal radius & 95.9 & $94.9 \mathrm{~ns}$ & $94.2 \mathrm{~ns}$ & - & $93.8-$ & $94.3 \mathrm{~ns}$ \\
\hline 18 Prosthion radius & 102.7 & $101.9 \mathrm{~ns}$ & $101.0 \mathrm{~ns}$ & - & $100.8-$ & $100.9 \mathrm{~ns}$ \\
\hline
\end{tabular}

ns: not significant, ${ }^{*}$ : significant at the $5 \%$ level, ${ }^{* *}$ : significant at the $1 \%$ level, - : no data available.

Note:

Kanto district

E1: Hitotsubashi series of early to middle Edo period by CAIMJC;

E2: Pooled data of Unkoin-1, Unkoin-2, Higashiueno and Joshinji series of late Edo period;

M1: Pooled data of Chiba and Kanto by CAIMJC collected in 1912-1944; Kinki district

E2: Cranial data of late Edo period excavated in Osaka by KANDA (1959);

M1: Pooled data of Kyoto and Osaka-1 by CAIMJC collected in 1870s-1944;

M2: Pooled data of Osaka-2 and Kinki by CAIMJC collected in 1945-1970s.

CAIMJC: Commission of Anthropological Investigation of Modern Japanese Crania.

measurement items that distinguish between the two groups identified in the cluster analyses (Fig. 2). Group 1 consists of Tohoku, Kanto, Chiba, Chubu, Niigata, Hokuriku, Kyoto, Osaka-1, Kumamoto, and Northern Kyushu. Group 2 consists of Osaka-2, Kinki, Nagasaki and Kagoshima.

The results are shown in Table 5 and Fig. 3. All the samples except Chiba were correctly discriminated by maximum cranial breadth alone.

\section{Discussion}

I. Effects of measurement errors and sampling bias

Before interpreting the inter-population differences in the modern Japanese crania, we must examine their significance in reference to factors such as the inter-observer measurement errors and sampling bias. The distance measures (Table 2) indicate that the inter-population differences in the modern Japanese cranial data, 


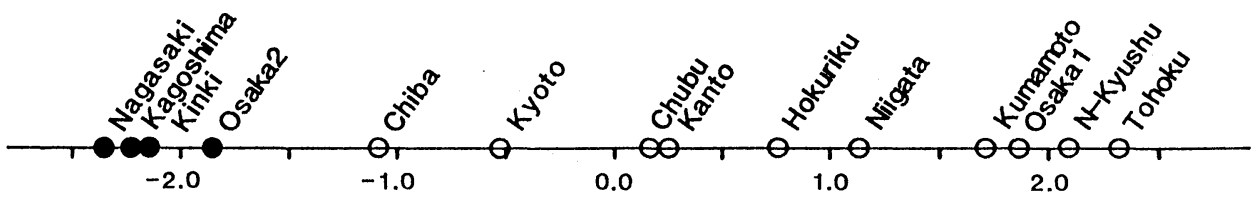

Fig. 3. Discriminant scores of 14 modern Japanese populations.

$O$ : belonging to cluster 1 , : belonging to cluster 3 .

compiled by CAIMJC, are much greater than the differences caused by systematic inter-observer measurement errors. However, there are some distance values that are smaller than the differences resulting from the bias of the samples. The materials used to estimate the differences caused by the bias of the samples consisted of cranial series belonging to the late Edo period (which lasted about 100 years) excavated in Tokyo. Also, Edo, one of the biggest cities in the world at that time, was characterized by a low birth rate and needed population inflow from surrounding areas to maintain its population (KITOH, 1983). These factors may cause the overestimation of the differences attributed to the bias of the samples. Though the results of the test of inter-population differences (Table 4) suggest a very slow secular change in the Edo period, the effects of the sampling bias may still be overestimated due to in-migration to Edo during the late Edo period. Therefore, it may be concluded that the inter-population differences in the modern Japanese crania are substantially greater than the differences caused by the bias of the samples.

Table 5. Discriminant function to distinguish between the two modern Japanese clusters calculated after stepwise variable selection from 18 measurement items

\begin{tabular}{lr}
\hline \multicolumn{1}{c}{ Measurement item } & Coefficient \\
\hline Maximum cranial breadth & $\begin{array}{r}-0.96179 \\
135.67377\end{array}$ \\
Constant & $92.9 \%$ \\
\hline Rate of correct discrimination & 9 \\
\hline
\end{tabular}

II. Inter-population difference and secular change

Chubu and Kumamoto samples were collected during the period S2, but belonged to the cluster consisting of samples collected before World War II in the dendrograms obtained by cluster analyses. For Chubu, this can be explained by the unusual age distribution. In most of the populations, $40-70 \%$ of the subjects are younger than 40 , and $5-20 \%$ are 60 years or older. However, in the Chubu sample, more than $70 \%$ are 60 years or older, and only $5 \%$ are younger than 40 . Therefore, though crania of the Chubu sample were collected in the period S2, their average year of birth is not much different from those of other samples collected in the period S1.

For the Kumamoto sample, this explanation does not apply. Very small cranial breadth may be a real characteristic of the people of this region. The average maximum breadth of the male crania excavated from Kuwashima Island in Kumamoto Prefecture (which are considered to be from the victims of a small pox epidemic in 1839 (Tempo 10)) is only $131.0 \mathrm{~mm}(\mathrm{~N}=13)$ (WAKI, 1970). This value is very small even in the Edo period (Table 4).

Out of 13 cranial measurement items with significant inter-population differences, seven items show significant secular changes in the Kanto or Kinki districts (Tables 3 and 4). Also, the key characteristic in determining the interpopulation differences is maximum cranial breadth (Table 5) which has exhibited remarkable 
secular change. Therefore, if the effects of the secular change could be eliminated, the interpopulation difference in the modern Japanese crania would be much smaller.

There are two ways to interpret the role of secular change: as a confounding factor and as a causative factor. If the secular change is regarded as a confounding factor, we must eliminate its effects before interpreting the interpopulation differences in modern Japanese crania. Since it is impossible to control the years of collection, years of birth of the cranial materials, or to correct the data for secular change, the simplest way to minimize the effects of the secular change is to use only the measurement items with significant inter-population differences, but without significant temporal differences. These measurement items are minimum frontal breadth and the four measurement items concerning the depth of the face (facial length, NAR, SSR, and PRR). It is doubtful, however, whether analyses based only on these measurement items would be informative.

On the basis of the temporal change in the geographic distribution pattern of the cephalic index, KoUCHI $(1983,1986)$ suggested a hypothesis that the regional difference in the tempo and timing of secular change is a major cause of geographic difference in cephalic index of the modern Japanese. The present results, in which more than half of the cranial measurement items with significant inter-population differences show significant temporal differences, do not contradict this hypothesis. The present results indicate that maximum cranial breadth is the key characteristic for determining the interpopulation differences. Since maximum head breadth has experienced the most remarkable secular change in the last 70 years (KOUCHI, 1986), it is likely that the inter-population difference in the CAIMJC cranial data is strongly influenced by the secular factor. This conclusion does not necessarily apply to the inter-population differences in the prehistoric and historic periods when a rapid secular change has not been demonstrated.

\section{Acknowledgments}

The authors wish to express their sincere gratitude to Prof. Kazuro HANIHARA of International Research Center for Japanese Study for the information on the age distribution of the cranial materials and to the following professors and doctors for the information on the period of collection of the cranial materials: Prof. Yukio DODO of the Department of Anatomy, Sapporo Medical College, Prof. Susumu KATO of the Department of Anatomy, Jikei University School of Medicine, Prof. Iwataro MORIMOTO of the Department of Anatomy, St. Marianna University School of Medicine, Prof. Katsuji KUMAKI and Dr. Tadasu YAMADA of the Department of Anatomy, School of Medicine, Niigata University, Prof. Kazumichi KATAYAMA of the Laboratory of Physical Anthropology, Faculty of Science, Kyoto University, late Prof. Yukitaka TERAKADO of the Department of Anatomy, Medical School, Osaka City University, Prof. Sanae KANDA of the Department of Anatomy, Hyogo College of Medicine, Prof. Masafumi NAGAI of the Department of Anatomy, Faculty of Medicine, Kyushu University, Prof. Yoshiatsu NAITO of the Department of Anatomy, Nagasaki University School of Medicine, Prof. Shosuke KAWAMURA of Department of Anatomy, Faculty of Medicine, Kumamoto University and Prof. Takahiko OGATA of Department of Anatomy, Faculty of Dentistry, Kagoshima University. The authors also wish to express their profound gratitude to Prof. Banri Endo of the Department of Anthropology, Faculty of Science, The University of Tokyo, for his kind permission to examine the crania kept in the Department of Anthropology 
and Prehistory, University Museum, The University of Tokyo, and to Dr. Emiko TSUTSUMI of the Institute of Human Life Science, Otsuma Women's University for her help in processing the discriminant analysis. Special thanks are also due to Dr. Hiroshi HosHI of the University of Tokyo for his valuable discussions that helped us in preparing this manuscript.

$$
\text { 抄録 }
$$

現代日本人頭骨の地域差之時代変化

河内まき子・小泉清隆

現代日本人頭骨計測値の地域性に影響を与える要因 として, 計測誤差, 標本のサンプリングによる偏り, 時代変化がある. 計測誤差およびサンプリングにより 生じる差をコントロールとして集団間差の大きさを評 価し，現代日本人頭骨にみられる地域差と時代差の関 連を検討することを目的として, 現代日本人頭骨研究 班による近世アイヌをふくむ日本人15集団間の差を分 析した. 計測誤差とサンプリングによる差のためのコ ントロールとして東京都出土の江戸時代後期の男性頭 骨延べ13集団を用いた，また，江戸時代以後における 頭骨計測值の時代変化を調べるために，江戸時代およ び現代日本人頭骨を比較した。計測誤差が小さい項目 を用いた多変量解析の結果, 現代日本人頭骨の集団間 差は計測誤差よりはるかに大きく，全体としてみれば サンプリングによる差に比べてあ大きい，資料の収集 年度を検討すると, クラスター分析の結果に基づくア イヌを除く現代日本人 14 集団のグループ分けは時代変 化の影響をかなり強く受けていると考えられる. 判別 分析の結果によれば, このグループ分けに最む大きな 影響をむつ項目は頭骨最大幅である。統計的に有意な 集団間差を示す項目の多くは時代変化をあ示すため, 明治から昭和時代にかけて集められた頭骨資料に基づ いて, 時代変化の影響をとり除いた地域差を分析する ことは難しいであろう。

\section{References}

Commission of Anthropological Investigation of Modern Japanese Crania, (Ed.), 1981: Data for Geographical Variations in Modern Japanese Crania, Tokyo.

Commission of Anthropological Investigation of Modern Japanese Crania, (Ed.), 1983: Data for Geographical Variations in Modern Japanese Crania 2, Tokyo.
HANIHARA, K., M. KOUCHI and K. KOIZUMI, 1982: A preliminary analysis of geographical variations in the male Japanese crania. J. Anthrop. Soc. Nippon, 90: 139-152.

HASEBE, K., 1917: Local differences in Japanese skulls. J. Anthrop. Soc. Nippon, 32: 285-296. (In Japanese)

[長谷部言人, 1917 : 日本人頭蓋の地方的差異. 人類 学雑誌, 32 : 285-296.]

HOWELLS, W.W., 1973: Cranial variation in man. Pap. Peabody Mus. Archeol. Ethnol., vol. 67, Harvard Univ. Press.

IKEDA, J. and A. TAGAYA, 1980: Geographic variation of the anthropometric measurements in the Japanese Islands. J. Anthrop. Soc. Nippon, 88: 397-410. (In Japanese with English summary)

KANDA, S., 1959: Craniometry of the Kinai skulls. A report on the excavated skulls of the later Edo period. Jinruigaku Shuho, 25: 53-83. (In Japanese with English summary)

KITOH, H., 1983: Population History of Japan for the Last 2000 Years. PHP Kenkyusho, Kyoto. (In Japanese)

[鬼頭宏, 1983 : 日本二千年の人口史. PHP 研究所]

KOHAMA, M., 1960: An anthropological study of the Japanese: on the local difference and the origin of the Japanese. The Quarterly J. of Anthropology, 7: 56-65. (In Japanese)

[小浜基次, 1960 : 生体計測学的にみた日本人の構成 と起源に関する考察. 人類学研究, $7: 56-65$.

KOIZUMI, K. and M. KOUCHI, 1988: An analysis of measurement errors in mandibulometry with special reference to their influence on the results of interpopulation relationship analysis. J. Anthrop. Soc. Nippon, 96: 339-355.

KOUCHI, M., 1983: Geographic variation in modern Japanese somatometric data and its interpretation. Univ. Mus., Univ. Tokyo, Bull., 22.

KOUCHI, M., 1986: Geographic variations in modern Japanese somatometric data: a secular change hypothesis. Univ. Mus., Univ. Tokyo, Bull., 27: 93-106.

KOUCHI, M. and K. KOIZUMI, 1985: An analysis of errors in craniometry. J. Anthrop. Soc. Nippon, 93: 409-412.

MARTIN, R. and K. SALlER, 1957: Lehrbuch der Anthropologie. Dritte Aufl. Bd. I. Gustav Fischer Verlag, Stuttgart.

MATSUMURA, A., 1925: On the cephalic index and stature of the Japanese and their local difference. J. Fac. Sci. Imperial Univ. Tokyo, Sec. V, I. Part I.

SAKURA, H. and Y. MIZOGUCHI, 1983: Measurement errors in craniometry. J. Anthrop. Soc. Nippon, 91: 69-78. 
SUZUKI, H., 1969: Microevolutional change in Japanese population from the prehistoric age to present-day. J. Fac. Sci. Univ. Tokyo, Sec. V, Vol. 3, Part 4: 279-308.
WAKI, T., 1970: Anthropological study on the skulls of the Edo period people excavated from Kuwashima Island in Ushibuka city, southern Amakusa district, Kumamoto Prefecture. Kumamoto Igakkai Zasshi, 44(11): 1031-1091. (In Japanese with English summary)

\section{河 内 まき 製品科学研究所応用人間工学部 干305 つくば市東 1-1-4}

Makiko KOUCHI Human Engineering Department, Industrial Products Research Institute 1-1-4 Higashi, Tsukuba, Ibaraki 305, Japan 